\title{
Spory pomiędzy posesorami a chłopami dóbr Cieni i Michałowa w czasach Księstwa Warszawskiego*
}

W Rzeczpospolitej Obojga Narodów chłopi mieli ograniczony dostęp do sądu w sporach z właścicielami lub dzierżawcami dóbr, w których mieszkali i pracowali. W szczególności nie mogli zaskarżyć działań właścicieli do jakiegokolwiek sądu. W przypadku konfliktu z dzierżawcą zdarzało się natomiast, że chłopi (działający z reguły nie indywidualnie, lecz jako gromada) mogli się skarżyć do właścicieli dóbr. Najlepiej znany jest sposób funkcjonowania referendarzy królewskich, którzy rozstrzygali spory między chłopami z królewszczyzn a ich dzierżawcami. Skargi na dzierżawców chłopi mogli składać także w części dóbr duchownych ${ }^{1}$ i latyfundiów magnackich ${ }^{2}$. Zdolność sądowa chłopów uległa znacznemu rozszerzeniu po rozbiorach ${ }^{3}$, choć sądownictwo za-

* Tekst przygotowany w ramach projektu „Uregulowania prawne relacji pomiędzy dziedzicami a chłopami na centralnych ziemiach polskich w okresie od zniesienia poddaństwa do uwłaszczenia”, finansowanego przez Narodowe Centrum Nauki (UMO-2018/31/B/HS5/00315).

${ }^{1}$ Na przykład Administracja Domowego Rządu rozpatrywała supliki chłopów z dóbr prymasowskich. Zob. J. Topolski, Położenie $i$ walka klasowa chłopów $w$ XVIII w. w dobrach arcybiskupstwa gnieźnieńskiego, Warszawa 1956, s. 224.

${ }^{2}$ R. Orłowski, Położenie chłopów w dobrach Ordynacji Zamojskiej w drugiej połowie XVIII w., „Annales Universitatis Mariae Curie-Sklodowska”, sectio F, 1952, nr 7, s. 160.

${ }^{3}$ Stosunkowo szybko w zaborach pruskim i austriackim: S. Michalkiewicz, Historia społeczno-gospodarcza chłopów polskich w zaborze pruskim [w:] S. Inglot (red.), Historia chtopów polskich, t. 2, Warszawa 1972, s. 55; R. Rozdolski, Stosunki poddańcze w Galicji, t. 1, Warszawa 1962, s. 67. W zaborze rosyjskim proces ten przebiegał znacznie wolniej: Z. Stankiewicz, Sytuacja prawna Polaków na Litwie, Białorusi i Ukrainie w latach 1772-1863 [w:] J. Bardach (red.), Historia państwa i prawa Polski, t. 3: M. Senkowska-Gluck (red.), Od rozbiorów do uwłaszczenia, Warszawa 1981, s. 852-853. И.А. Исаев, История государства и права России, Moskwa 1996, s. 203-209 i 260-268. 
chowało w dużej mierze charakter stanowy. Utrzymało się także sądownictwo patrymonialne, mimo iż dwory monarsze - zwłaszcza berliński i wiedeński wykazywały nim wyraźne zainteresowanie.

Utworzenie przez Napoleona Księstwa Warszawskiego z większości ziem polskich zagarniętych w XVIII w. przez Prusy wiązało się z daleko idącą reformą organizacji sądownictwa. Przede wszystkim zyskało ono charakter powszechny w tym znaczeniu, że właściwość sądu mogła zależeć od przedmiotu sporu, ale nie od przynależności stanowej powoda i pozwanego. Zatem zarówno szlachta, jak i przedstawiciele pozostałych warstw (chłopi, mieszczanie, Żydzi) mieli oddawać swoje spory pod rozwagę tych samych sądów, których struktura była bardzo jak na owe czasy - prosta. Sprawy cywilne miały być rozpatrywane przez sądy pokoju, trybunały cywilne pierwszej instancji, sąd apelacyjny oraz sąd kasacyjny. Do spraw karnych powołano sądy policji prostej (sprawowane m.in. przez podsędków, którzy zostali umieszczeni w strukturze sądów pokoju), sądy policji poprawczej, sądy sprawiedliwości kryminalnej oraz sąd kasacyjny. Pojawiły się ponadto pierwociny sądownictwa administracyjnego.

Formalnie powszechne sądownictwo zachowało jednak w pewnych aspektach w praktyce zabarwienie stanowe. Jak zauważył Władysław Sobociński, „sąd pokoju w Księstwie był dla szlachty tylko do pojednań i spraw niespornych; właściwym sądem był przede wszystkim dla mas ludności miast i wsi”"4. Ponadto dziedzice jako wójtowie rozpoznawali niejednokrotnie sprawy o wykroczenia popełnione przez chłopów zamieszkujących ich dobra ${ }^{5}$.

Co więcej, 21 grudnia 1807 r. Fryderyk August wydał tzw. dekret grudniowy $^{6}$, mocą którego pełna własność gospodarstw chłopskich została przyznana dziedzicom - chyba że chłop był w stanie wykazać, iż za „dobrowolnym układem" zostało mu nadane prawo własności. W praktyce pozbawiało to znaczną część ludności chłopskiej Księstwa użytkowego prawa własności ziemi, które dotąd im przysługiwało. Akt królewski nie regulował problematyki zdolności sądowej chłopów, niemniej Hipolit Grynwaser ocenił, że dekret „usuwał rząd od wtrącania się do stosunków pomiędzy silnym panem a słabym włościaninem"7. Nie ograniczono jednak możliwości regulowania stosunków między dworem a wsią przez sądy. Przypadki występowania gromad chłopskich przeciwko dziedzicom do sądów oraz sporów sądowych z odwrotnym układem

${ }^{4}$ W. Sobociński, Historia ustroju i prawa Księstwa Warszawskiego, Torun 1964, s. 244.

${ }^{5}$ Ibidem, s. 283.

${ }^{6}$ Dziennik Praw [Księstwa Warszawskiego], t. 1, 1807, s. 10-12.

${ }^{7}$ Czesław Rajca pisze, że dziedzice robili wszystko, by ich nadużycia nie były rozpatrywane na forum publicznym. Zob. Cz. Rajca, Ruch oporu chłopskiego w Królestwie Polskim w latach 1815-1864, Warszawa 1969, s. 92. 
procesowym nie były rzadkie, choć określenie skali zjawiska na obecnym etapie badań nie jest możliwe ${ }^{8}$.

Przeprowadzona wraz z Tomaszem Królasikiem kwerenda akt Trybunału Cywilnego Kaliskiego ${ }^{9}$ z czasów Księstwa Warszawskiego ujawniła około stu terminów rozpraw, na których rozpatrywano spory między dziedzicami a chłopami osiadłymi w ich dobrach. O niektórych sprawach świadczą pojedyncze zapiski, po innych zachowało się po kilka lub kilkanaście protokołów. Do najlepiej udokumentowanych konfliktów należy spór między Kacprem ${ }^{10}$ Jackowskim i Gabrielem Głodowskim a gromadami wsi Cieni i Michałowa ${ }^{11}$, który także ze względu na swoją wielowątkowość zasługuje na opracowanie.

Pierwszy odnaleziony protokół pochodzi z 3 stycznia $1809 \mathrm{r}^{12}(\mathrm{I})^{13}$. Po stronie powodowej występuje gromada wsi Cieni, pozwanym zaś jest Gabriel Głodowski. Z protokołu nie wynika, czego konkretnie dotyczył spór (w znajdującym się na początku tomu spisie spraw został opisany jako o possessorio ${ }^{14}$ ), ale wiadomo, że trwał jeszcze od czasów pruskich i że do jego rozstrzygnięcia niezbędne jest wysłanie na grunt komisji, do której Trybunał oddelegowuje jednego ze swych asesorów (Andrzeja Rodewalda).

Pół roku później, 20 lipca 1809 r. ${ }^{15}$, sporządzono kolejny protokół (II). W roli powoda występuje w nim Kacper Jackowski, zaś pozwanymi są gminy Cieni i Michałowa ${ }^{16}$. Trudno jednak dowiedzieć się z niego czegokolwiek o meritum

8 Przykłady spraw sądowych między włościanami a dziedzicami: mieszczanie i włościanie dóbr osieckich sądzili się z Potockim o „prawo do wolnego wrębu” (AGAD, Archiwum Gospodarcze Wilanowskie, t. 35, k. 75 i nn.); chłopi gminy wsi Woli Gołębiowskiej do miasta Radomia należącej prawowali się z Józefem Hirszem, posiadaczem Wójtostwa Gołębiów (AGAD, Komisja Rządowa Spraw Wewnętrznych, t. 2804a: wyrok sądu pokoju - s. 35 i nn., wyrok trybunału cywilnego pierwszej instancji - s. 46 i nn.); proces włościan zyplewskich z dziedziczką omawia Hipolit Grynwaser (Pisma, t. 2, Wrocław 1951, s. 241 i nn.). Na znaczną skalę tego rodzaju sporów za rządu pruskiego zwraca uwagę Jan Wąsicki, Przyczynek do dziejów walki klasowej ,olędrów” wsi Chmielinka w latach 1793-1806 [w:] idem, Ziemie polskie pod zaborem pruskim. Fragmenty dziejów, Zielona Góra 1978, s. 138.

${ }^{9}$ AGAD, zespół: Trybunał Cywilny Kaliski [dalej: AGAD, TCKal.].

${ }^{10}$ Imię Kacper było w protokołach różnie zapisywane: Kasper (np. AGAD, TCKal., t. 292, s. 251), Gasper (np. AGAD, TCKal., t. 291, s. 413).

${ }^{11}$ Hasło: Cienia (powiat kaliski, parafia Opatówek), Stownik geograficzny Królestwa Polskiego, t. 1, Warszawa 1880, s. 688; hasło: Michałów (gmina i parafia Opatówek), Stownik geograficzny Królestwa Polskiego, t. 6, Warszawa 1885, s. 300.

12 AGAD, TCKal., t. 1, k. 37-37v.

${ }^{13}$ Liczby rzymskie w nawiasach oznaczają kolejne rozprawy (audiencje) trybunału.

${ }^{14} \mathrm{Z}$ protokołu z 7 maja wynika, że chłopi domagali się m.in. zwrotu pewnych gruntów (AGAD, TCKal., t. 194, k. 25v.).

15 AGAD, TCKal., t. 705, s. 69-70.

16 Autor protokołu pisze o stawających plenipotentach gminu wsi Cieni i niestawającym gminie Michałowa. Można jednak przypuszczać, że pozwane zostały po prostu obie gminy, zaś protokół jest nieprecyzyjny. 
sprawy, ponieważ dotyczy on tylko kwestii formalnych - nieprawidłowego pozwania gmin, które stało się przyczyną odroczenia sprawy ${ }^{17}$.

Z protokołu rozprawy, która miała miejsce dziewięć dni później, 29 lipca 1809 r. (III), można wywnioskować, że roszczenie Jackowskiego ma charakter pieniężny, zaś chłopi nie chcą go uiścić, ponieważ ze względu na zadłużenie dóbr nie wiedzą, wobec kogo powinni spełnić swoje zobowiązania:

Lubo pozwane Gromady przez swych Patronów dlatego, że dobra te zadłużone, nadto że też pod subhastę podpadają i już termina do tejże subhastacji wyznaczone zostały. Powoda od toczenia tej sprawy odsunięcia domagają się. Trybunał jednak dla tego że na powoda hipoteka jest wystawiona tegoż pro competenti actore uznaje i sprawę wprowadzać pozwala. Po wprowadzeniu sprawy relacje Wmu Michalskiemu asesorowi uczynić zaleca, która na audiencji trybunału środowej w dniu 16 sierpnia roku bieżącego w przytomności stron i ich obrońców bez zapozwów stanąc mają ${ }^{18}$.

Kolejny zachowany protokół sporządzono ponad pół roku później, 20 marca 1810 r. ${ }^{19}$ (IV). Na rozprawie tej po stronie powodowej wystąpiła gromada włościan wsi Cieni, która pozwała Gabriela Głodowskiego i Kacpra Jackowskiego, nazwanych w protokole posiadaczami tejże wsi. Tym razem przejściu do meritum sporu przeszkodziła okoliczność, że o sprawie nie został powiadomiony prokurator $^{20}$. Także kolejna rozprawa, z 9 kwietnia 1810 r. $^{21}(\mathrm{~V})$, nie przybliżyła sądowego rozstrzygnięcia sporów między posiadaczami dóbr a chłopami. Doszło bowiem do jej odroczenia ze względu na zaniedbania pełnomocników gmin, które znowu znalazły się po stronie pozwanej ${ }^{22}$.

Należycie przedmiot sporu opisuje dopiero protokół z 7 maja 1810 r. (VI):

[...] powodowie wystosowanymi powództwami i skargą powrócenia sobie przez pozwanych nieprawnie przywłaszczonych gruntów Wilcza Niwa i lasu Brzozowego Gajecznik zwanych i innych Ról od pozwanych niesłusznie sobie odjętych,

17 Tom nie zawiera spisu spraw, do którego mógłby zostać wpisany przedmiot sporu.

18 AGAD, TCKal., t. 291, s. 413-414.

19 AGAD, TCKal., t. 292, s. 251-252.

${ }^{20}$ A powinno tak się stać, skoro stroną postępowania była gmina. Por. art. 83 pkt 1 Code de procédure civile: édition originale et seule officielle, Paris 1806.

${ }^{21}$ AGAD, TCKal., t. 3, k. 533.

22 „Trybunał po wysłuchaniu publicznie relacji, gdy się okazało, iż ur. Jański i Nieszkowski patronowie pozwanych w całym toku tej sprawy zaniedbali przytoczyć na obronę stron całkiej pliki dokumentów która się znajduje przy aktach, przeto po wysłuchaniu także wniosków urzędu publicznego trybunał, zważywszy, że z zaniedbania tego mogłaby jaka szkoda dla strony wyniknąć, stanowi, że sprawa niniejsza po uskutecznionych komunikacjach w przeciągu tygodni czterech wyprowadzoną być powinna" (AGAD, TCKal., t. 3, k. 533). 
oraz nadgrodzenia sobie użytku z nich zabranego, niemniej utrzymania siebie przy dawnych powinnościach dworowi Cieńskiemu pełnić zwykłych, stosownie do opisu praw im nadanych dopominając się i na dowód swego twierdzenia wyrok posesoryjny zgasłej regencji Kaliskiej między teraźniejszymi stronami pod dniem 16 listopada roku 1805 nastąpiony, a pod dniem 1 grudnia roku tegoż stronom ogłoszony Role Włościanom Cieńskim przez powodów zabrane przysądzający, i używania onych tym pozwanym zabraniający, jako też wstrzymania się od użytku Lasu Brzozowego Gajecznik onymże aż do rozsądzenia sprawy in petitioris zakazujący, a powodom tenże użytek przyznający, oraz Inwentarz powinności tychże włościan względem dworu Cieńskiego przez Księdza Jana Zygla komisarza prymasowskiego w Skierniewicach pod dniem 23 czerwca roku 1796 ułożony i przez tegoż z wyrazem swej pieczęci podpisany w Wyciągu wiarygodnym składają, i że im te role pozwany na komisji przez wyżej wspomnianego asesora we Wsi Cieni ze zlecenia swego trybunału odbytej dnia 24 marca r.p. przez zgodę w posesję oddać przyrzekł, i nazajutrz przez tegoż delegowanego też Role powodom w posiedzielstwo oddanymi zostały wnoszą, jednak że pozwany ur. Głodowski niedługo po tym Powodom role wspomniane na powrót odebrał, utrzymują, jako też, że ich pozwany ur. Głodowski do nadzwyczajnych nad opis Prawa powinności i Robocizn pociągał - wnoszą ten jednak punkt swoich roszczeń do osobnego procesu sobie zachowują, i że gruntów i pobudynków są właścicielami, i te sobie wzajemnie sprzedawali, przekładają i aby przy nich i inwentarzu powinności przez księdza Zygla podpisanego dworowi Cieńskiemu pełnić mianych utrzymanymi byli żądają ${ }^{23}$.

Chłopi występowali zatem przeciwko Jackowskiemu i Głodowskiemu z dwoma roszczeniami. Po pierwsze, domagali się zwrotu lasu i pola, które zapewne miały w przeszłości charakter serwitutów, a które posesorzy dóbr zajęli na wyłączność. Po drugie, zdaniem chłopów Jackowski i Głodowski próbowali nakładać na nich pańszczyznę i czynsze w nadmiernej wysokości. Z kolei pozwani twierdzili, że nie odebrali chłopom żadnych gruntów i że nie są związani wymiarem powinności chłopskich ustalonym przez poprzednich właścicieli. Trybunał przyznał w pełni rację chłopom - nakazał wydać sporne grunty oraz pobierać tylko te świadczenia i tylko w takiej wysokości, w jakiej zostały one opisane w inwentarzu z 1796 r. Jackowski i Głodowski zostali ponadto obciążeni kosztami procesu.

Na 9 października 1810 r. ${ }^{24}$ (VII) datowany jest protokół, który poświadcza, że Kacper Jackowski wystąpił wobec chłopów z Cieni i Michałowa ze znacznie dalej idącym roszczeniem - sprawa została bowiem opisana jako „o ustąpienie z włości”. Termin jednak spadł ze względu na chorobę pełnomocnika Michałowa.

${ }^{23}$ AGAD, TCKal., t. 294, k. 25v.-26.

${ }^{24}$ Protokół zachowany w dwóch tomach: AGAD, TCKal. t. 5, k. 137-137v. i t. 716, k. 24 (sentencjonarz spraw szybkiego zadecydowania wymagajacych). 
W dniu 15 listopada 1810 r. $^{25}$ (VIII) trybunał ponownie ocenił, że pełnomocnicy gmin nienależycie wykonali swe obowiązki i mając na uwadze art. 481 Code de procédure civile ${ }^{26}$, wyznaczył kolejnego pełnomocnika oraz odroczył sprawę.

Rozstrzygnięcie w sprawie żądania „o ustąpienie z włości” zapadło 28 marca $1811 \mathrm{r}^{27}$ (IX). Ze względu na jego doniosłość wypada przytoczyć znaczne jego fragmenty:

Wniosków i sporów stron stawających wysłuchawszy gdy powód pokładając wykaz hipoteczny wsiów Cieni i Michałowa siebie dziedzicem tychże dóbr być okazuje, a stąd aby obydwie pozwane gromady Cieni i Michałowa do zawarcia nowych układów zniewolonymi lub w przypadku oporu do ustąpienia z[e] swych siedlisk znaglonymi zostali, żąda; na poparcie zaś żądania swego przywodzi, iż lubo niektórzy z pozwanych włościan dokumenta mają, te jednak wcale nic nie znaczą gdy tylko od księży ówczasowych rzeczonych dóbr posiadczów bez zezwolenia Stanów Rzeczypospolitej dawane, do ich tylko śmierci ważnemi były, składając oraz co do wsi Cieni lustrację kanonika Sigla pod d. 23 czerwca 1796 roku, zaś co do wsi Michałowa kontrakt sześcioletni tegoż kanonika Sigla pod dniem 21 czerwca 1796 temi dowodzić pragnie, że włościanie w rzeczonych dobrach żadnej własności nie mają, i że zawsze pewne daniny i robocizny odmieniając ich sposób dominium od nich wybierało. Przeciwnie zaś pozwana strona a mianowicie gromada Cieni pokładając dokument w roku 1489 w piątek przed [Zielonymi] Świątkami wydany, którym wykazuje się przez arcybiskupa gnieźnieńskiego sławetnej Agnieszce w Opatówku zamieszkałej, sześć łanów roli darowane były, przywodząc oraz, że jeszcze jedna część po niejakim Włojku pozostała, która w roku 1330 za 30. Marków kapitule gnieźnieńskiej z prawem odkupu zastawiona była, twierdząc niemniej jak i gromada Michałowa, że od niepamiętnych czasów w spokojnej posesji zostają i jeden drugiemu swe grunta z zabudowaniami i gospodarstwem odprzedawali i odprzedają w dowód czego wiele podobnych kontraktów składają wystawiając na koniec, że z teraźniejszym dziedzicem w żadne układy wchodzić nie mogą, gdy rzeczone dobra są zadłużone i już za Rządu Pruskiego dla niezapłacenia sumy szacunkowej resubhastacja nakazaną była, uchylenia powoda z[e] skargą jego dopraszają się. Trybunał za tym z jednej strony zważając, że powód co do dziedzictwa rzeczonych dóbr prawo swe okazał, z drugiej strony że obydwie pozwane gromady wraz z zabudowaniami przez siebie przedsięwziętemi od dawnych czasów (czego sam powód nie zaprzecza) posiadają jedynie tylko zaprzeszłych dziedziców to jest biskupów gnieźnieńskich (którzy sporu podobnież co do ich własności nigdy nie czynili) w daninach czynszach robociznach i pańszczyznach niektóre odmiany co do oko-

${ }^{25}$ Protokół zachowany w dwóch tomach: AGAD, TCKal., t. 5, k. 343-343v. i t. 716, k. 24-24v. (sentencjonarz spraw szybkiego zadecydowania wymagajacych).

26 Art. 481: „Rząd, gminy, instytuty publiczne, i małoletni, będą także dopuszczeni do restytucji, jeżeli wcale bronionymi nie byli, albo nie byli bronionymi ważnie".

${ }^{27}$ AGAD, TCKal., t. 6, s. 409-412. 
liczności czasu ceny produktów zachodziły a stąd prawa takowego przeszło lat 30 używając już tym samym gdy w spokojnej posesji zostawali, chociaż prawa własności zupełnego nie okazują, to im podług wszelkiego prawa z odmianami robocizny danin i.t.d. tym bardziej przysądzone być winno, że i powód nie w inszym stanie oraz prawie takowe dobra nabył, zważając oraz że członki składające gromady gdyby były podług żądań powoda exmitowane nie tylko szacunek dóbr spadłby lecz nadto od tylu lat osiadłe krajowi szkodę przez niezamieszkanie sprawićby mogły. Z tych więc przyczyn wniosków urzędu publicznego wysłuchawszy zgodnie z nimi stanowi [Trybunał], że pozwane gromady Cieni i Michałowa przy gruntach i budynkach niemniej inwentarzach, jak dotychczas te posiadają, utrzymują się. W celu zaś ustanowienia danin, czynszu i innych powinności przez gromady pozwanemu odbywać się mianych stosownie do teraźniejszych czasów [i] okoliczności ur. Michalskiego asesora deleguje, który na wezwanie strony pilniejszej i za użyciem biegłych których strony w przeciągu dni trzech podać winny podług ilości i gatunku posiadanych gruntów i ich użytków daniny i czynsze niemniej robocizny odbywać się przez pozwanych miane ustanowi i dzieło swe pod zatwierdzenie trybunału prześle.

Trybunał oddalił więc żądanie Jackowskiego, aby została orzeczona eksmisja chłopów z jego dóbr. Charakterystyczne, że uzasadnienie prawne wyroku jest nader skąpe - nie przywołano żadnego artykułu Kodeksu Napoleona ani nie odwołano się do dekretu grudniowego. Jest to zrozumiałe $\mathrm{z}$ dwóch powodów. Po pierwsze, trybunał kaliski rzadko w uzasadnieniach swych orzeczeń umieszczał rozbudowane rozważania prawne - z reguły ograniczał się do wskazania podstawy prawnej rozstrzygnięcia. Po drugie, zacytowany werdykt nie jest łatwy do uzgodnienia z obowiązującym ówcześnie prawem pozytywnym zwłaszcza z dekretem grudniowym. Sam Kodeks Napoleona rzeczywiście nie był zbyt pomocny przy wydaniu omawianego rozstrzygnięcia. Zdaje się, że trybunał poczynił w nim jedynie aluzję do uregulowanej m.in. w art. $2262 \mathrm{KN}$ instytucji przedawnienia (trzydziestoletni termin). Poza tym Kodeks Napoleona był mało przydatny, ponieważ w ogóle nie regulował własności podzielonej, której dalsze istnienie trybunał zdaje się akceptowaćc ${ }^{28}$. Jednocześnie „ustawa przechodnia" ${ }^{29}$ zachowywała w mocy istniejące prawa. Z kolei dekret grudniowy zdaje się usprawiedliwiać żądanie Jackowskiego. Wypada w tym miejscu przytoczyć art. 1 i 5 tego dekretu:

${ }^{28}$ Co bynajmniej nie było stanowiskiem odosobnionym. Zob. A. Heylman, Rozbiór wykazu hipotecznego, Warszawa 1858, s. 14; J.K. Wołowski, Kurs kodexu cywilnego, Warszawa 1868, t. II, s. 95 i nn. Ostatnio bibliografię dotyczącą własności podzielonej w Królestwie Polskim zebrała Dorota Wiśniewska w pracy: Własność prefabrykancka w Łodzi w latach 1820-1866, Łódź 2019.

${ }^{29}$ Dziennik Praw [Księstwa Warszawskiego], t. 2, s. 84 i nn. - zwłaszcza art. 9. 
Art. 1. Każdy rolnik, włościanin i z wyrobku żyjący, niemający już poprzednio za dobrowolnym układem nadanego sobie prawa własności lub na lata udzielonego, wolny jest wyprowadzić się z miejsca, w którym dotąd zostawał, i przenieść się w obrębie Księstwa Warszawskiego tam, gdzie dobra wola jego będzie.

Art. 5. Rolnik na koniec wyprowadzający się ze wsi, w której dotąd pozostawał, winien oddać dziedzicowi własność tegoż dziedzica gruntową składającą się z załogi i zasiewów. Od tego obowiązku uwolnionym być nie może, tylko w zdarzeniu, gdyby udowodnił, iż tę własność utracił po pierwszym dniu października 1806 r. czy to przez pomór, czyli przez inną klęskę. Wszelkie inne pretensje, które by dziedzic mógł mieć do rolnika, a ten onemuż zaprzeczał, nie mogą być wyciągane, tylko przez zaskarżenie obwinionego do sądu, w żadnym jednak zdarzeniu dziedzic rolnika poniewolnie zatrzymać nie może, a swej na nim własności zaprzeczonej w sądzie dochodzić jest mocen.

Dekret nie tyle znosił więc własność podzieloną ${ }^{30}$, ile ustanawiał domniemanie, że gospodarstwa uprawiane indywidualnie przez chłopów stanowią własność dziedzica - chyba że chłopi dysponują „dobrowolnym układem”, na podstawie którego uzyskali prawo własności, przy czym twórcy dekretu rozumieli je nie jako kapitalistyczną własność uregulowaną w art. $544 \mathrm{KN}$, lecz jako własność użytkową. Jak wielu chłopów w Księstwie dysponowało takimi dokumentami, nie wiadomo. $Z$ pewnością jednak nie należały one do rzadkości ${ }^{31}$. Czy stosownymi kontraktami dysponowali włościanie z Cieni i Micha-

${ }^{30}$ Tak twierdzi Helena Brodowska: ,utracili oni bowiem przysługujące im formalnie prawo dziedziczenia posiadanych osad. W bezwzględny dla chłopów sposób dekret grudniowy znosił podzieloną między chłopów a dziedziców własność feudalną. Na jej miejsce, zgodnie z burżuazyjnym duchem prawa, wprowadzał czysta własność prywatna. Odrzucał z niej wszystko, co miało jakieś pozory wspólnoty, i wyłączał wszelkie oddziaływanie państwa na rozwój własności. Powstała burżuazyjna własność osadnicza - oczyszczona z feudalnych więzów podziału i wspólnoty - wolna od wszelkich praw chłopa”. Zob. H. Brodowska, Historia społeczno-gospodarcza chłopów polskich w zaborze rosyjskim [w:] S. Inglot, Historia chłopów polskich, t. 2, Warszawa 1972, s. 320. Jeszcze bardziej kategoryczny sąd wyraziła Filomena Bortkiewicz, stwierdzając, że po wprowadzeniu dekretu ,[w]szystkie poprzednie postanowienia odnoszące się do stosunków chłopów z dziedzicami utraciły moc i zostały zastąpione odpowiednimi artykułami nowego kodeksu". Zob. F. Bortkiewicz, Nadziały i powinności chlopów pańszczyźnianych $w$ dobrach prywatnych Królestwa Polskiego, Warszawa 1958, s. 18.

${ }^{31}$ Dysponowali nimi z reguły różnego rodzaju koloniści (Hollendrzy), osiedli zarówno w okresie przedrozbiorowym, jak i za czasów, kiedy późniejsze ziemie Księstwa znajdowały się pod władzą Prusaków i Austriaków. Niemniej i wśród ludności etnicznie polskiej popularna była choćby instytucja zakupieństwa. Zob. C. Bobińska, Polskie zakupieństwo a francuska censive, „Acta Universitatis Lodziensis. Folia historica” 1992, t. 46, s. 49 i nn. Por. J. Mazurkiewicz, Znaczenie akt notarialnych dla badań nad własnościa w Księstwie Warszawskim i Królestwie Polskim, „Annales Uniwersitatis Mariae Curie-Skłodowska", sectio F, 1965, nr 7, s. 120. Tadeusz Mencel szacuje, że w momencie wydania dekretu grudniowego ok. 80\% gospodarzy nie miało umów (T. Mencel, Znie- 
łowa? Na podstawie zachowanych protokołów trudno to stwierdzić. Należy to jednak uznać za mało prawdopodobne. Jako „dobrowolnych układów”, o których mowa w dekrecie, nie można raczej traktować przywołanych w wyroku średniowiecznych dokumentów z 1330 i 1489 r., zwłaszcza że dotyczą one tylko Cieni (i to na dodatek prawdopodobnie jedynie części gruntów). Tym bardziej „dobrowolnym układem” nie był inwentarz z 1796 r. Zdaje się więc, że trybunał uznał za podstawę uprawnień chłopów zwyczaj oraz dobro powszechne, a nie spisane umowy. Charakterystyczne jest przy tym podzielenie kosztów procesu na pół, co sugeruje, że zdaniem sądu sprawa nie zakończyła się jednoznacznym zwycięstwem żadnej ze stron, mimo że roszczenie Jackowskiego zostało oddalone (w myśl art. 130 Code de procédure civile koszty procesu obciążały stronę, która przegrała).

Omówiony wyrok 28 marca 1811 r. nie zakończył bynajmniej sporów w Cieni i Michałowie. W dniu 10 lipca $1811^{32}$ (X) trybunał musiał wyznaczyć biegłych, którzy wraz z asesorem Michalskim mieli określić wysokość powinności w myśl wyroku z 28 marca $1811 \mathrm{r}$. Kwerenda ujawniła protokoły z jeszcze dwóch rozpraw, które miały miejsce 28 lutego 1812 r. $^{33}$ (XI) i 1 maja 1812 r. $^{34}$ (XII). Obie audiencje dotyczyły postępowań egzekucyjnych. Pierwsze było związane z egzekucją z dóbr Cienia, co zdaniem chłopów mogło naruszyć ich prawa, drugie gruntów chłopskich w Cieni. Oba wyroki są korzystne dla chłopów (oba postępowania egzekucyjne były prowadzone nieprawidłowo).

Przytoczone dwanaście orzeczeń (z których część dotyczy kwestii wpadkowych) nie pozwala rzecz jasna na przedstawienie wniosków natury ogólnej. Aby je sformułować, należałoby przebadać wiele podobnych spraw, a i tak generalizacja będzie trudna ze względu na odmienność poszczególnych stanów faktycznych. Niemniej omówiony materiał pozwala na przedstawienie przynajmniej dwóch wniosków jednostkowych, które stoją w sprzeczności z dotychczasową narracją historyczną (zwłaszcza z okresu PRL-u, kiedy temat wyzysku chłopów i ich oporu przeciwko temu wyzyskowi był popularnym tematem badawczym). Po pierwsze, zdominowany przez szlachtę sąd nie zawsze stawał po stronie szlachciców-posesjonatów w sporze z chłopami. Po drugie, chłopskie prawa do ziemi wcale nie wygasły wraz z ogłoszeniem dekretu grudniowego.

sienie poddaństwa w Księstwie Warszawskim na tle porównawczym, „Acta Universitatis Lodziensis. Folia Historica" 1983, nr 13, s. 30).

32 AGAD, TCKal., t. 7, k. 217.

${ }_{33}$ AGAD, TCKal., t. 9, k. 271 i nn. oraz t. 724, k. 123.

${ }^{34}$ AGAD, TCKal., t. 9, k. 438 i nn. 


\title{
DISPUTES BETWEEN THE LANDOWNERS AND THE PEASANTRY \\ IN THE DUCHY OF WARSAW PERIOD. CASES OF CIENIA AND MICHAŁÓW VILLAGES
}

\begin{abstract}
The relations between the gentry and the peasantry in the Duchy of Warsaw period show their undoubtedly transitional character. The capitalistic civil law which was imposed by France did not harmonize at all with the partially feudal realities of the Polish countryside. Napoleon abolished serfdom in Article 4 of the Constitution. Soon after, Frederick Augustus I of Saxony issued the December Decree (1807). Its significance as well as consequences, despite the wealth of the literature concerning this subject matter, are extremely difficult to define even today. In the Polish People's Republic period, which was definitely a period of very intensive research into the issues of the exploitation of the peasants and their resistance in the feudal and bourgeoisie eras, it was claimed that the Decree abolished the shared ownership of farms and deprived the peasants of their rights (the abolition of dominium utile). These categorical conclusions were, as a rule, formulated without taking the court records into consideration. Furthermore, these records actually seem to indicate that the reality was much more complicated. The article delineates the disputes between the peasantry of two villages, Cienia and Michałów, and their landowners (or vice versa) before the Civil Tribunal of First Instance in Kalisz. It is worth mentioning that according to the peasants' awareness as well as to judge's opinions the December Decree did not put an end to the mutual rights and obligations between the gentry and the peasantry that had been shaped by customs and various documents which had been issued for centuries.
\end{abstract}

Keyw ords: peasants' duties, Napoleonic Code, Duchy of Warsaw 